\title{
Social Media Marketing: Visitors Decision to Green Destination
}

\author{
Arief Budiman, H. Mokh. Adib Sultan, Ayu Krishna Yuliawati \\ Management Study Program \\ Universitas Pendidikan Indonesia \\ arief.budiman@upi.edu
}

\begin{abstract}
In Indonesia, activities to preserve the environment have been a common practice in the tourism industry. With its potential, West Java has initiated the development of tourism as a core business of development. Attractions and cultural art in Bandung, West Java, are rich in diversity, as reflected in the acronym "Gurilaps" (gu = gunung (mountain), ri = rimba (jungle), $\mathrm{l}=$ laut (sea), $\mathrm{a}=$ air (water), $\mathrm{p}=$ pantai (beach), $\mathrm{s}=$ seni budaya (art and culture), and making this tourism industry become one of the core business out of the six (6) core businesses of West Java. The use of social media as a marketing medium through the Internet is considered to have a great potential to increase and raise the value of a product or a tourist destination in the eyes of tourists. The research method used survey method and simple regression analysis. The effect of the use of social media which consists of High Quality Content, Easy Navigation, Lurk, Contact Strategy Participate, Updated Information indicators on the increase of visit is low. This can be improved by more listening and involve with the conversations that occur on social media.
\end{abstract}

Keywords: Green Destination, Social Media.

\section{INTRODUCTION}

Indonesia relies heavily on its wealth and natural beauty so that become a useful commodity for tourism. Many regions in Indonesia offer natural beauty and one of them is the province of West Java which has a lot of potential for tourism. West Java is endowed with a variety of potential tourism including \pm 350 attractions that reside in Bandung. Attractions and cultural art in Bandung are rich in diversity, as stated in the West Java Provincial Regulation No. 10 of 2008, have the motto Gurilaps, acronym for Gunung, Rimba, Laut, Air, Pantai, dan Seni budaya (Mountain, Jungle, Sea, Water, Beach, and Arts and Culture) with the basic concept of Guar Akarna, Pelak Sikina, Piara Tangkalna Sangkan Kapetik Hasilna, Kaala Buahna [1]. This makes the tourism industry as one out of six (6) core businesses in Bandung with a target of one million foreign tourist visits and forty million domestic tourists.

However, a conflict of economic value utilization of natural resources in Indonesia, which led to the destruction of nature and many other behavioral and tourism operations that have not been in favor of the environment and are very detrimental to tourism in Indonesia. In fact, the nature is a capital that needs to be maintained if the tourism industry wants to survive in the long term [2].
The increasing global awareness of environmental sustainability including Gurilaps make tourism cannot be separated from the issue. Tourism and sustainable environment have been intertwined [3]. Tourists demand environmentally friendly destinations, so that it becomes one of the keys for the destination in order to continue to compete competitively because of the increasing demand of tourists to Gurilaps tourism.

Throughout time, the marketing mix need to be changed because of changes occurring in an environment wherein consumers and businesses live, work, compete, and make a purchasing decision. As the main organizer of Gurilaps destination especially in Bandung, the Bandung Tourism Office is deemed to have less concerned about the forces that could affect they future. Marketing research is a key to understanding the environment. Knowledge of environment is not only helpful in modifying existing marketing mix, but also to identify new opportunities [2]. According to the American Marketing Association, a marketing research is the function that links the consumer, customer, and public to the marketer through information which is used to identify and define marketing opportunities and problems; produce, refine, and evaluate marketing efforts; monitor marketing performance; and improve understanding of marketing as a process [4]. Marketing research specifies the information required to address these issues; designing a method for collecting information; manages and implements the data collection process; analyze the results; and communicate the findings and their implications.

In Indonesia, researches on Gurilaps tourist destinations are very few, so that Gurilaps tourism is still difficult to develop. This research studies the decision to visit by domestic tourists and explore the potential of Gurilaps destinations in Bandung on an appropriate social media marketing model associated with Gurilaps tourism. This is because social media is considered as a medium that has a great power in the future and is considered to have great potential to increase and raise the value of a tourist product in the eyes of tourists because tourism community that has been formed and connectivity among tourists in it. This is the medium in which each brand has the opportunity to have their own media and able to engage consumers/tourists to participate or so-called consumer-generated content so that it has a more efficient communication, fast, and timely. 
Based on the aforementioned, problems in this field are weak socialization of Gurilaps destinations through social media in Bandung, the need for research on domestic tourists's visiting decision in choosing Gurilaps destinations in Bandung and research on models of social media marketing in Gurilaps tourism in Bandung. Thus, this study will discuss the following matters:

1. Analyzing social media marketing especially the student community of nature lovers to Gurilaps destinations in Bandung.

2. Analyzing the factors which affect domestic travelers especially the student community of nature lovers in the decision to visit Gurilaps destinations in Bandung.

3. Examining the effect of social media marketing on the decision to visit Gurilaps destinations in Bandung. Literature Review

\section{LITERATURE REVIEW}

\section{A. Social Media}

Internet is always a social media. It is a unique one because it is the first form of many-to-many communication channel. Telephone is a one-way communication. While the broadcast is a one-to-many communication [5]. Internet is so unique because each person is able to communicate with the rest of the world. Social media has arrived and the customers love it. Social media give customers the control. Marketers have a choice: join the conversation or fail to communicate with customers [5].

The number of users on social networking websites and Internet users desire to network is a potential and significant opportunities that marketers need to fully understand their customers. As social media are currently getting more customers' attention stronger than the other websites, social media has become a powerful marketing tool as well as high potential [5].

Social media allows marketers to reach and interact with consumers to provide value with relatively low cost and provide more impact than traditional media channels. However, it also poses a major threat to take control over the creation and dissemination of content that is too far from the company. Most organizations do not understand the impact of social media on their operations make them vulnerable to this threat [5]. This theory aims to make the concept of social media from both philosophical and functional perspective in order to provide an integrated framework, which identifies the driver, antecedents, actions, and the consequences of a successful social media marketing efforts. Conceptual framework proposed here is developed from the existing literature on interactive marketing, consumer behavior online, and Web 2.0.

Social media is not just a marketing tool. It is effectively a new way to run a business. It requires a new corporate culture, which in turn requires the support of the wider company, systemic and incentives. It requires a new pattern: more listening, reducing the 'shouts' [6].
Social media is the place where the Word of Mouth turns into ballistics. Word of Mouth does not happen spontaneously, so the first thing you want to measure is the impact generated by the publication made by you [6]. Social media allows marketers to build public voice and presence on the web and strengthen other communication activities. Because of the proximity of their day, they can also encourage companies to remain innovative and relevant [5].

Social media channels according to [5], among others: Blogs, Social Networking, Social Content, Social Recommendation, and Social Bookmarking. Stephen [11] explained that social media channels include Blogging, Microblogging, Social Networking, Media Sharing, Social News and Bookmarking, Ratings and Reviews, Forum, and the Virtual World.

According to [5] there are several factors of customer satisfaction on the performance of the social media run by the company.

1) High quality content

Besides being able to reveal the desired target market when viewing the website, marketers can also ensure that the site run by the company is more relevant by using scenario planning, personas, sizzles, and customer engagement.

\section{2) Easy navigation}

A good social media is certainly very concerned about the requirements as to the form and function of social media. Form here means social media page views, in the form of beauty including the form layout, graphics, color and typhography. Function is in the form of the interaction, integration, navigation and structure. There are three rules to make a good navigation for a social media:
a) Keep it simple
b) Be consistent
c) Signpost

\section{Lurk (listen and learn)}

Lurk is how the company can listen to customers, understand what they need, make a dialogue with customers on a regular basis, always give customers good values (never break a promise), and in particular provides an interesting surprise for customers.

\section{Participate (response, join the conversation, post a comment)}

The company can take a chance with their social media to engage and follow the conversations that are formed in accordance with the company's mission, and announce the company's activities, events and competitions that the company makes on social media. In the event of the conversation in another community, add the announcement on the chat if there is a relationship and have benefits.

\section{Contact strategy (acknowledging the order, confirming delivery dates)}

The company's strategy in the form of a contact strategy: first, the organization has been catching prospect e-mail address and name and, secondly, structured contact strategy. 
Each contact (e-mail, letter or telephone) usually contain incentives call to action. Usually there is a different order depending on whether the customer is registered for e-mail newsletters, try a product, or actually make a purchase. Making a purchase is just the beginning of what is expected is a lifelong relationship. Some forms of contact strategy is to acknowledge the order, confirm the delivery date, and provides advanced form of satisfaction surveys.

\section{Updated information}

Every social media that the company own and use basically need to be attractive as well as updated, so that it allow users and customers to feel comfortable and not easily bored in accessing information on the company.

\section{B. Decision to Visit}

Visitors to a tourist attraction have characteristics and visit patterns, each with different need or reason for a visit to a tourist attraction and these need to be considered for tourism providers so as to provide a product that match the interests and needs of visitors [10]. The visitor characteristics include:

a. Sexes that are divided into male and female

b. The age of the respondent at the time of the survey

c. City or region as the respondents' origin of residence

d. The level of education of respondents

e. Employment status of respondents

f. Marital status of respondents

g. Revenue per month of respondents

The number of users on social networking websites and Internet users desire to network is a potential and significant opportunities that marketers need to fully understand their customers. As social media is now getting more customers' attention stronger than the other websites, social media has become a powerful marketing tool as well as high potential [7].

Characteristics of visitors can be divided into two types, namely socio-economic characteristics and the travelling characteristics [2]. In this case, the visitor characteristics gives indirect influence on the tourism development. Steps that must be performed cannot be applied directly by looking at the characteristics of the visitors, but need to see the connection with the perception of visitors.

When observed, the people who come to visit any place or country, are usually referred to as visitors that consists of some people with various motivations including the tourists, so not all visitors are tourists. According to the International Union of Official Travel Organization (IOUTO) visitors are every person who comes to a country or other residence and generally for any purpose except to do the job of receiving wages [8].

Similar definition is conveyed by the World Tourism Organization that a visitor for statistical purposes, is every person who visits a country that is not an own state for any reason other than to get a job that paid by the countries they visit [8]. Thus there are two categories of visitors, namely:

1. Traveler (Tourist), is a visitor who stay while at least for 24 hours in the countries during visit and the purpose of the journey can be classified into the following classifications: a. Leasure for recreational purposes, vacations, health, studies, religious and sport.

b. Trade relations (business), families, conferences, missions and other so forth.

2. Excursionist, a visitor who lives in a country during visit in less than 24 hours.

Furthermore, World Tourism Organization also stated that a domestic tourist is a resident of a country who travel to some place in the region of the country, but outside the neighborhood daily for a period of at least one night and no more than one year and the purpose of this journey is not to Iearn money from the places visited [9].

\section{RESEARCH METHOD}

The present study was conducted with the marketing approach, particularly regarding the influence of social media marketing on the decision to visit Gurilaps destination in Bandung. Furthermore, this study will examine two variables, namely the independent and the dependent variable. The independent variable under study is social media marketing, while the dependent variable is the decision to visit Gurilaps destinations in Bandung. Respondents in this study are nature lovers member of MAHACITA UPI (a students community) active in social media and visited Gurilaps destinations in Bandung. Samples in this study are 88 active members of the students community of nature lovers Mahacita UPI. The study was conducted using the Internet sampling technique. Those who do not use the Internet do not have the opportunity to be the sample, although they may be part of the target population. Among Internet users, consumers who do not visit the site in question or who do not visit the site are not part of samples. In addition, those who visit the site briefly have little chance to be part of those who frequently visit the sites [3]

This study is based on the time dimension that is conducted in less than one year from April 2014 up to October 2014, then according to [11] the research method used is a cross-sectional research, the research which is done at one time (single point or one point in time) with different unit of analysis.

The method used in this study is causal-comparative method [11] because this study used a causal relationship and the independent variables are not manipulated. Based on data collection, this study uses survey data collection techniques. Definition of the survey is restricted to the research whose data are collected from upper samples to represent the entire population and the information are collected from the upper sample or respondent to represent the entire population using questionnaires or interviews. With existing information technology, the survey questionnaire can also be done by phone and e-mail [11].

According to [11], research survey is a research (with the exception of the electronic messages and Internet surveys) where an interviewer interacts with the respondents to obtain facts, opinions, and attitudes. A new survey of marketing experts found that the most common source of market research information is data survey. $88 \%$ of companies use online method to conduct market-based research survey. $65 \%$ of 
those surveyed agreed that the speed of online research has helped accelerate the pace of their business. Moreover, the number of Internet users worldwide continues to explode. Consequently, the characteristics of a country's population and the characteristics of Internet users tend to mingle.

Based on the investigation plan and structure arranged in such a way that the study use correlational design. [11] Explains that the quantitative correlational design seeks to investigate the values of two or more variables and test or determine relationships or interrelationships that exist between them in a particular environment. According to [11] the research design is included in a causal study research design. A causal study is the study or research that studies whether a variable cause or determine the value of other variables. In a causal study, researchers investigate whether the value of one variable causes or determines the value of other variables, in an attempt to establish the relationship between these two variables.

Through this causal or correlational study, it can be obtained a picture of the relationship of social media marketing as the independent variable by the Gurilaps destinations management in Bandung with visiting decision as the dependent variable in the consumer survey in the Student Community Nature lovers MAHACITA UPI. This study will test whether there is an influence of social media marketing on visiting decision on the Gurilaps destination in Bandung.

As mentioned in the research object that the subject matter under study is rooted in two things: the application of social media marketing as an independent variable $(\mathrm{X})$ and purchasing decision as a dependent variable (Y).

\section{RESUlt AND DisCUSSION}

\section{A. Correlation Analysis}

TABLE II. CORRELATIONS

\begin{tabular}{|l|l|l|l|}
\hline \multicolumn{2}{|l|}{} & $\begin{array}{c}\text { decision to } \\
\text { visit }\end{array}$ & $\begin{array}{l}\text { medsosmarke } \\
\text { ting }\end{array}$ \\
\hline $\begin{array}{l}\text { Pearson } \\
\text { Correlation }\end{array}$ & decision to visit & 1.000 &, 172 \\
\hline & Medsosmarketing &, 172 & 1.000 \\
\hline Sig. (1-tailed) & decision to visit &. & 044 \\
\cline { 2 - 4 } & Medsosmarketing &, 044 &. \\
\hline $\mathrm{N}$ & decision to visit & 100 & 100 \\
\cline { 2 - 4 } & Medsosmarketing & 100 & 100 \\
\hline
\end{tabular}

Source: Result of Data Processing using SPSS 18.0 for Windows, 2014

Based on the results of data processing in the table above, it can be seen that the correlation coefficient between social media marketing with the decision to visit is 0.172 . Based on the interpretation of the correlation coefficient table references, the correlation coefficient between social media marketing with the decision to visit $(0.172)$ is in the interval from 0.00 to 0.199 indicating a very low level of correlation.
Positive correlation value indicates that more and more and intensively socialize through social media marketing then predictably domestic tourists visiting the decision is likely to increase.

Significance of the correlation coefficient (measured by probability) both variables obtained value of 0.044 . That is, because the probability below 0.05 , it can be concluded that there is a significant correlation between social media marketing with the decision to visit.

\section{B. Simple Linear Regression Analysis}

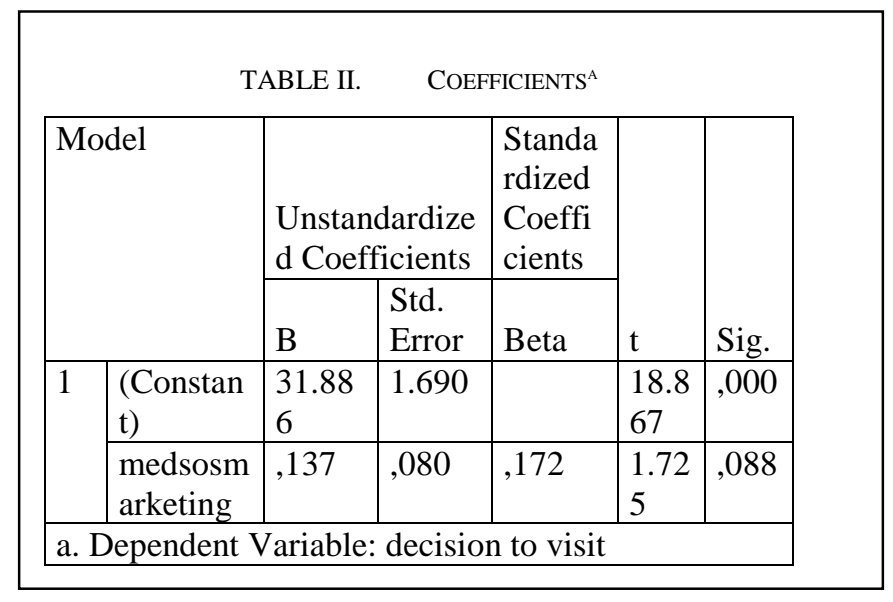

Source: Result of Data Processing using SPSS 18.0 for Windows, 2014

Simple linear regression equation for social media marketing and the decision to visit are as follows:

$$
\begin{gathered}
Y=a+b X \\
Y=\mathbf{3 1 . 8 8 6}+\mathbf{0 . 1 3 7} \mathbf{X} \\
\text { Decision to visit }=\mathbf{3 1 . 8 8 6}+\mathbf{0 . 1 3 7} \text { Social Media Marketing }
\end{gathered}
$$

Based on the above regression equation indicates if the value of the constant 31.886 social media marketing is ignored then the decision to visit is 31.886. Regression coefficient on the variable of social media marketing is 0,137 which means that if the value of social media marketing is increased by one unit, then the value of the decision to visit will increase by 0,137 .

TABLE III. MODEL SUMMARY ${ }^{\mathrm{B}}$

\begin{tabular}{|l|l|l|l|l|}
\hline \multicolumn{1}{|c|}{ Model } & \multicolumn{1}{|c|}{$\mathbf{R}$} & R Square & $\begin{array}{c}\text { Adjusted R } \\
\text { Square }\end{array}$ & $\begin{array}{l}\text { Std. Error of } \\
\text { the Estimate }\end{array}$ \\
\hline $\begin{array}{l}\text { dimension0 } \\
1\end{array}$ &, $172^{\mathrm{a}}$ &, 029 & 3.69345 \\
& & & \\
\hline
\end{tabular}


PRESS

R-Square value or coefficient of determination obtained by $2.9 \%$. R-Square value ranged between numbers from 0 to 1 . R-Square value greater that is close to 1 indicate that the models are formulated to explain the decision to visit of domestic tourists is very high. While the R-square value in the table is equal to 0,029 , the domestic tourists visiting decision is still low because there is much close to 1 . The meaning of the value of R-Square is that $2.9 \%$, the domestic tourists visiting decision is influenced by social media marketing.

\section{CONCLUSION}

An overview of the application of social media includes Social Networking (Facebook), microblogging (Twitter), Blog (Tumblr), Photo and Video Sharing (Instagram and YouTube), and Forum are at the low category. Based on this study, it is found out that the highest use of the social media is Easy Navigation, meaning that ease in finding information about Gurilaps Destinations in Bandung. While the lowest indicator is High quality content, meaning that a very low quality of the content of social media Gurilaps Destinations in Bandung.

The overview of the increase in visiting Gurilaps Destinations in Bandung is considered very low. For indicators that have the highest earnings is the place where the selection indicator is easier to find information Gurilaps destinations in Bandung is relatively easy. For indicators with the lowest acquisition is the choice of service requirements where accuracy tourist destination facility in Bandung still does not meet the expectations of the tourists.

The use of social media affect the formation of decision to visit which indicates a perfect positive correllation. While the effect of the use of social media which consists of indicators High Quality Content, Easy Navigation, lurk, Contact Strategy Participate, Updated Information of $2.9 \%$, meaning that the effect of variable $\mathrm{X}$ to $\mathrm{Y}$ is low.

\section{MANAGEMENT IMPLICATION}

Based on the research findings, the following statements are made in the hope of benefit and an input for woven handicraft industry, particularly for managers of tourist destinations in Bandung, which are as follows. Based on the results of the use of social media variable $(\mathrm{X})$ which has a score that is undervalued, for indicators Content (Content) that is the respondent's interest in the update of the information presented by Gurilaps destination managers in Bandung on social media, this can be overcome by always updating the content regularly and continuously, the site manager (administrator), which is more friendly to the consumer in this case tourists. Furthermore, there is a need to inform consumers about the latest information. For indicator Participate Contact Strategy, things that need to be considered is very high enthusiasm on the respondent to discuss Gurilaps Destinations in Bandung on social media. This can be improved with more listening and want to get involved with the conversation that occur on social media, by doing so consumers are more appreciated and creates positive online word of mouth.

Based on the research findings, variable of increase in visit (Y), the indicator of service requirements, the management of tourist destinations should improve facilities and remarkable destinations service system in accordance with the expectations and desires of tourists.

Suggestions for the next study, it is expected that future researchers will conduct a study on Gurilaps destinations in Bandung through other variables that may affect the increase in visit, such as considering the variables Functional Building Blocks Of Social Media, Viral Marketing Online and The Effectiveness of Electronic Word of Mouth Communication that give more results and also the maximum contribution for researchers and managers Gurilaps destinations in Bandung.

\section{REFERENCES}

[1] Peraturan Daerah Provinsi Jawa Barat http://www.bphn.go.id/data/documents/08pdprovjabar010.pdf

[2] Gössling S, et al. 2005. The eco-efficiency of tourism Ecological Economics. Volume 54, Issue 4, 15 September 2005, Pages 417-434.

[3] Ringbeck. J, El-Adawi. A, Gautam.A.2010. Green Tourism: A Roadmap for Transformation. Booz and Co Publisher.

[4] Kotler, Philip and Keller, Kevin Lane. 2012. Marketing Management. Prentice Hall. New Jersey.

[5] PR Smith \& Ze Zook.2011. Marketing Communication: Integrating Offline and Online With Social Media. Kogan Page. United Kingdom.

[6] Stern, L., El-Ansary, A., Coughlan, A. T. (1996). Marketing Channels. Englewood Cliffs, New Jersey. Prentice-Hall.

[7] Stephen, C. (2015). Social Media Analysis: A Business Imperative.

[8] International Recommendation on Tourism Statistic. 2007. United Nation and UNWTO. Madrid.

[9] McDaniel, Carl and Roger Gates. (2007). Marketing Research: Seventh Edition. USA: John Wiley \& Sons, Inc.9.

[10] Laroche.M, Bergeron J, Forleo G.B. 2001. "Targeting consumers who are willing to pay more for environmentally friendly products", Journal of Consumer Marketing, Vol. 18 Iss: 6, pp.503 - 520 .

[11] Ulber Silalahi.2010.Metode Penelitian Sosial. Refika Aditama. Bandung. 